\title{
Barakah: The Pilgrim's Divine Gift at the Shrine of Sunan Pandanaran
}

\author{
Abdul Haque Chang* \\ Department of Social Sciences, Institute of Business Administration (IBA), Karachi, Pakistan.
}

Received: July 07, 2019

Published Online: December 30, 2020

\begin{abstract}
Through the ethnographic examples and a framework of the everyday life, "The Pilgrim's Divine Gift at the Shrine of the Sunan Pandanaran" shows the important role which the shrine of saint Sunan Pandanaran, located in Bayat, Central Java, plays in the lives of the Javanese people. This paper shows how the Javanese sacred space is inclusive of a historical continuity of different faiths that make up the local culture. Exposing the unnoticed, the inconspicuous, and the unobtrusive, this paper goes beyond the settled cultural patterns and problematizes heterogeneities, ambiguities, and indeterminate classification of categories into a homogenous identity of place, culture, and state - one singular, unified entity. The shrine is an heirloom of the Javanese kingdoms of Surakarta and Yogyakarta-Sunan Pandanaran is considered an ancestor of the Mataram Kingdom - but through the efforts of a Catholic village chief, this shrine has been revitalized as an important pilgrimage site for Javanese of any religious affiliation.
\end{abstract}

Keywords: Pilgrimage, Divine Gift, Sufi Shrine, Islam in Java, Indonesia.

\section{Introduction}

Before entering the last gate at the shrine of Pandanaran, there is a fire pit where a juru kunci recites verses over the flowers brought by the pilgrims as offerings for the saint. The fire burns during the prayer sessions. Fragrant incense of a brand-named Sri Kresna and bearing his image $^{1}$ surrounded by snakes, made in Indonesia, is brought by Muslim pilgrims to burn in this fire pit. On top of the final gates before entering the tomb of the saint, there are three gold plates with figures. On the middle gate, there is a two-headed dragon statue guarding the saint between two identical meditating Buddha figurines. ${ }^{2}$ Two plates on the other gates show a gapura with two dragons with big tongues and tails, holding their claws in respect toward a gapura. Below these images are three low brown doors. Visitors have to duck their heads before entering. Inside the tomb, heads bowed, people sit cross-legged and recite verses in melodic and beautiful voices. Endless groups of pilgrims sing verses in praise of the saint, the prophet of Islam, and Sayyid Shaikh Abdul Qadir Gilani. They recite La illah illa 1lah, "There is no God but Allah," in the zikir called the Tahlil. ${ }^{3}$

Everyday places like the shrine of Sunan Pandanaran may offer, through common experiences, an uncommon temporal construction through the lenses of the known and unknown and the disintegration of the established dichotomy of heterogeneity and homogeneity. What does Islam mean at the shrine of Pandanaran, the Muslim saint of Java, where pilgrims seek 
blessings and protection? The saint is protected by dragons, and Buddha prays for his safety and well-being. Is this Hindu? Is it Buddhist or Islamic? Or is it all of these united?

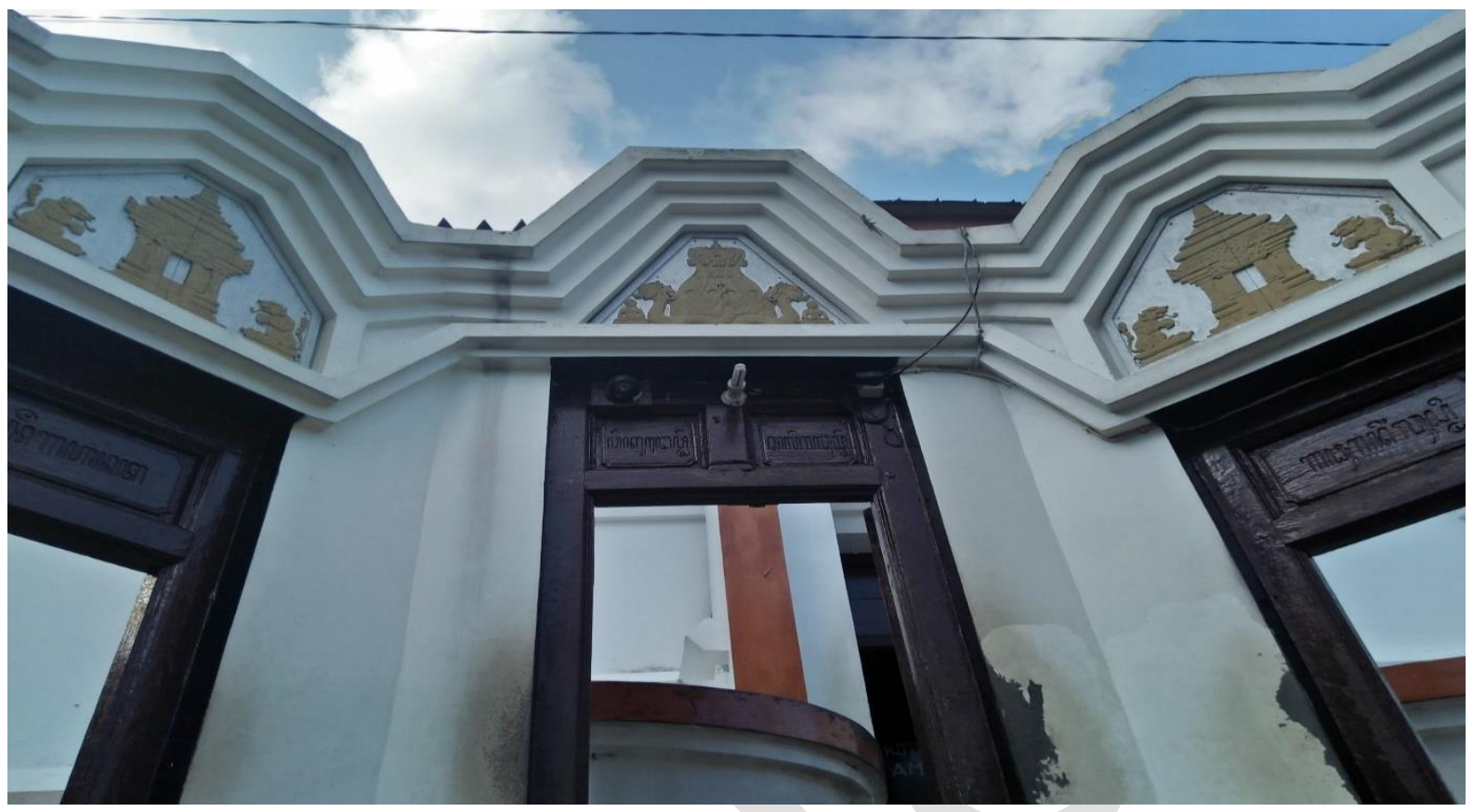

Figure 1. Three gates before entering the tomb of Sunan Pandanaran

\section{Theoretical and Methodological Approach}

What does this ambivalence tell us about the unnoticed, the inconspicuous, and the unobtrusive everyday life (Highmore, 2002) at the shrine of Sunan Pandanaran at Bayat, Klaten, in the central Java? According to the theoretical framework of everyday life and cultural theory, familiar spaces like the shrine of Sunan Pandanaran are submerged in the depths of everyday life despite their heterogeneous and ambivalent histories, which are decidedly undecided (Highmore, 2002).

What lies beneath the daily routine at the shrine of a Muslim saint of Java is the unsettled tension of the divergence of multitudes of heterogeneities, ambiguities, and indeterminate classification of categories into a homogenous identity of place, culture, and state-one singular, unified entity. Scholars have noted the merging of Hinduism and Buddhism to become not a hybrid religion but a new one, in which Shiva and Buddha, though two different entities, become essentially one. ${ }^{4}$ I suggest that not only have they become one, but, at the last gate of the shrine of Sunan Pandanaran, the figures of Buddha and Sunan Pandanaran have also become one through the unity in the plurality. Both disrupt the homogenous linearity of time, in which the successive chronology of Islam, Hinduism, and Buddhism has become disconnected from the historical time frame. An icon of Buddha lingers on at the shrine of the most eminent Muslim saint of Java, who popularized a tolerant version of Islam and brought a paradigmatic shift from Hinduism-Buddhism to Islam. At his shrine today, the meditating Buddha continues to associate history with mundane, everyday life and raptures the idea of homogenous empty time (Anderson, 2006; Lowy, 2005).

I am building the argument that the pluralism, diversity, and unity of such a metamorphosis in terms of Hindu, Buddhist, and other icons of Javanese heritage are not just present as the 
architectural style at the shrine of Pandanaran. These relics of the Hindu and Buddhist past are present everywhere in Indonesia, not only in preserved archaeological sites but in the replication of the Hindu-style gate called a gapura and the icons of Javanese, Balinese Hindu, and Buddhist materials and symbols that can be found everywhere: billboards, newspapers, streets, tourist destinations, royal courts, sacred sites, private homes, airports, hotels, restaurants, and clothes. They appear in the Ramayana. The iconography of Hindu, Buddhist, and Javanese heritage is enacted everywhere to authenticate the present.

However, this Hindu and Buddhist iconography has become a part of everyday routine in Indonesia. The otherness and strangeness have become diluted through continuous exposure. This same effect can be observed in Bayat at the shrine of Pandanaran in terms of framing and locating the diversity, heterogeneity, and multiplicity inherent in Sufism and the various beliefs coexisting with it. These elements, collectively, are the archives of everyday life that provide alternative readings on the fixed or already established categories of Islam, Sufism, Hinduism, and Buddhism. According to Highmore:

A good starting point would be to suggest that no form of discourse is ever going to be proper (appropriate) to everyday life. The everyday will necessarily exceed attempt to apprehend it. This would simply mean that the search for the perfect fit between a form of representation and its object (the everyday) needs to be called off. Instead we might say that different forms of representation are going to produce different versions of everyday life (2002).

The idea of spiritual continuity at the shrine of Pandanaran is a facet of Hindu, Buddhist, Javanese, and Islamic identity. A sacred place like the shrine of Sunan Pandanaran and its related objects and ideas is not exclusive to one group but intertwined with the collective cultural history and identity of Java. A pilgrimage is reenacted as a memory of the sacred past based on the composite repository of historical continuity. This continuity in everyday life today provides examples of how the shrine of Pandanaran and the diversity, multiplicity, and heterogeneity of its surrounding community create a lived phenomenon-not something that happened in the past, but a lifestyle that flourishes today.

This narrative is composed from my ethnographic encounters during my fieldwork at the shrine of Pandanaran and other sacred spaces in Klaten, Yogyakarta, and elsewhere in Java. These sites are connected with each other through the sacred geography of pilgrimage and the history of Java. I am writing principally about the shrine of Pandanaran, but it was very important to visit other shrines to develop a broader perspective about shrine culture in Java generally and about the shrine of Pandanaran particularly.

This is the narrative of how a Sufi sacred place was resurrected in modern times through the efforts of a Catholic village chief who, since 1974, has played an active role in the promotion of the shrine of Pandanaran by working with the community and government to improve the facilities for pilgrims. The shrine, as it developed, played a role in rebuilding the diverse-yet unified-surrounding community. The locals of other faiths help maintain the shrine and participate in its rituals as part of their identity as citizens of the village and of the Java. In essence, the people build the shrine, and the shrine builds the community, and the reciprocal process is best explained by the term barakah, a divine gift or blessing conferred by a saint for devotional service. 


\section{The Making of a Sacred Place}

Bayat is located in Klaten, in central Java. It has eighteen subdistricts (kelurahan). The shrine of Sunan Pandanaran is located in the village or subdistrict of Paseban, located twelve kilometers from Klaten City in the south. Yogyakarta is to the west, along with Wedi, a historic market town, and in the east is Solo City. In addition to the shrine of Sunan Pandanaran, Bayat has shrines of other famous Sufi saints such as Syeh Domba, Sayid Habib, Pangeran Wuragil, and Syeh Kewel.

Gua Maria Marganingsih, a Catholic pilgrimage site, is also located in Bayat, to the south of the shrine of Pandanaran. It has become a sacred attraction for the Catholic and Christian community, ${ }^{5}$ with regular visitors from the Solo, Yogyakarta, and Klaten. Initially, it was owned by one family, but is now under the administrative control of the parish of Bayat. It is also used as a church for Saturday and Sunday services under the name Santa Maria Ratu Catholic Church.

Near Bayat, the shrine of Bagus Burhan, alias Raden Ngabehi Rangga Warsita or Ronggowarsito (1802-1873), a famous Javanese poet, is located thirteen kilometers from the village of Paseban in Trucuk. Ronggowarsito's poetry is recited at the shrine of Pandanaran. Ronggowarsito's poems describe the biographical details, spiritual journey, and mystical ideas of Sunan Pandanaran. These poems provide a Sufi message about the life of Pandanaran to the common Javanese people. Ronggowarsito is especially famous for making prophecies in his poetry about the independence of Indonesia from Dutch colonialization.

Before 1970 Bayat was a small, sleepy village with limited public transportation. Most of the people used a horse-drawn carriage from Pasar Wedi, Klaten, Cawas, and nearby areas to reach Bayat. There was no electricity until 1987. People used Petromex oil lamps to light their homes, shops, and streets. The shrine of Pandanaran was also lit in this way. Pilgrims slept in the shrine complex; there were no guesthouses for visitors. A few people opened restaurants for the pilgrims, but these were small and temporary. Most of the people in the area made or sold batik. Affluent residents were usually batik traders. All the old houses in Bayat were large enough to contain a small batik workshop. The other major profession in Bayat was pottery. The area has very good soil, so it became famous for making different kinds of pottery for local use and to sell in Klaten, Yogyakarta, and Solo. The soil is also excellent for bricks, which are used in local construction. The area is also known for snacks made from rice, fish, and fruit.

Juru kunci, which means "key holder," are the caretakers of the shrine. Generations of these caretakers served at the shrine of the saint and assisted visitors with prayer services, accommodations, and food to receive barakah, a blessing from the saint. Economic prospects for juru kunci were not good, and earnings from the shrine were small, but they kept the tradition alive. The honor of serving the pious saint of Java and a connection to the sacred cosmology and the royal court of Yogyakarta and Surakarta were enough to keep the juru kunci working at the shrine with devotion. Most of the juru kunci inherit the position, but some are appointed by the local administration or community members, and some have become voluntary caretakers as part of their devotional relationship with the saint.

Although the shrine of Pandanaran is considered a historic sacred space in Java, however, before 1970 it was not a popular site for pilgrimage. Most of the pilgrims came to visit the shrine individually. It was not until 1974, when Franciskus Xavierius Suripto, generally known 
as Pak Suripto, a 28-year-old Catholic man, became kapala desa, or village chief, of Paseban, that the barakah began. The story of the making of the sacred place through the efforts of this village chief is cited by the people of Bayat as an important shift in their relationship with the saint and the shrine.

Pak Suripto began to plan with the people of Bayat and the tourism department to promote the pilgrimage site locally and at the national level. He visited other village chiefs in nearby areas, big cities, and small towns and invited them to come see the shrine. At the same time, he started to support the renovation and rehabilitation of the shrine through donations and entry fees. The first ticket for the shrine in 1974 was IDR $25 .{ }^{6}$ He supported local vendors by buying cement and construction material from them. Thus, began a new economic era for the people in Bayat. It was the first time a village chief had started a project that opened the possibility for further development. With the increasing number of pilgrims, the economy of Bayat began to improve, and the people began to benefit as a whole.

People started to convert their large houses, originally built as batik workshops, into penginapan, or guesthouses. Local women who previously had no permanent source of income started restaurants. Bayat changed drastically after 1986, when Pak Suripto realized that electricity was very important for the development of the area. At that time no government organization was able to provide electricity to the region. Pak Suripto campaigned with the other village chiefs and, with their support, managed to get a private electricity company to lay the grid and put-up poles in the area. It was a big risk, according to Pak Suripto, as the money needed for this project was huge, and if people had not turned in their donations, it might have ended in disaster. "Without taking risk, it is not possible to do something which is impossible," Pak Suripto said. "Initially, people thought it was a kind of joke that someone was thinking to bring electricity to the region when even the government wasn't able to do so, but after it succeeded, people began to trust me."

After electricity reached the area, people began to convert their batik workshops into stalls to sell batik, clothes, snacks, fruit, tea, and coffee. The people of Bayat considered this a barakah as a result of the leadership of Pak Suripto, which lasted from 1974 to 1990. It was during this time that the shrine of Pandanaran became a national pilgrimage site for Sufis or those who believed in the role of Sunan Pandanaran in spreading a tolerant version of Islam.

However, even before it became a popular destination for pilgrims, not all visitors were Muslims. Many pilgrims from the Semarang region were ethnic Chinese who had Christian, Buddhist, and other religious beliefs and claimed Sunan Pandanaran was originally Chinese and came to Semarang from China. Bayat was attracting not just Muslim pilgrims but also people of other religions. According to Pak Suripto, "Our aim was not to make this place exclusive for one group or another, but we wanted to open the doors of the shrine for each and every one, regardless of religious belief, faith, and ethnic origin." The shrine of Sunan Pandanaran is considered a Muslim pilgrimage place, but, according to Pak Suripto, "There are Hindu, Christian, Buddhist, and people who have different kinds of beliefs and faith. It is, in a way, a neutral place for everyone, and there is no restriction on how to perform pilgrimage."

But the most important factor in making Bayat a popular place for pilgrimage in Indonesia and abroad was Abdurrahman Wahid (1940-2009), known as Gus Dur. He was the eminent leader of the Nahdlatul Ulama ${ }^{7}$ and later become president of Indonesia from 1999 to 2001. His visit to the shrine in 1998 before becoming president conveyed an important message for the 
Nahdlatul Ulama cadre. Shortly afterward, he appealed to the Nahdlatul Ulama to make a pilgrimage to the shrines of the nine saints of Java, including Sunan Pandanaran. The real change, however, came after Gus Dur visited the shrine after becoming president. People began to visit the shrine in busloads and caravans. The bus tours catapulted Bayat to a renowned pilgrimage destination. Since 2000 , the area has been termed "a city that never sleeps."

Gus Dur's visit issued a political statement about preserving the roots of Javanese culture and Sufi Islam, which had been under strict regulations during the Suharto era. This post-Suharto political freedom allowed the general public to visit the shrines of Sufi saints in Java. The importance of deceased ancestors is critically important in Javanese culture, so the relaxation of these rules restored a collective sense of identity to Javanese pilgrims.

The shrine is open twenty-four hours a day. The twelve juru kunci have divided their duties into different shifts. They provide the prayer services and take care of the shrine. Many houses in Bayat have been converted to shops, guesthouses, toilets, parking areas, restaurants, supermarkets, fruit shops, food vendors, and places of prayer. On special days there is a night market near the parking area, where vendors from nearby areas sell honey, natural oils, skin care products, local medicinal plants, toys, and cheap electronics. Thus, the making of Bayat into a sacred place is in a way the narrative of how a village chief reinvented the place through opening possibilities for the pilgrims, so they can visit the shrine, and for the people of Bayat, so they can improve the local economy. It provides a different way to think about community dynamics and captures the story of how a Catholic revitalized the Muslim tradition of ziarah, honouring the saints.

In Sufi tradition visiting a saint's tomb is a way to get a blessing from the saint. However, this reinvention of ziarah by Pak Suripto, though submerged in the mundane narrative of everyday life in Bayat, provides an important nexus for how sacred places can be accessed through different trajectories to bring a tradition to life.

\section{The Sense of Community}

In Bayat people gather all the time for social activities. This sense of community is one of the important dynamics for understanding the culture in Bayat and the rural areas of central Java. In the theoretical framework of this research, the everyday life experiences at the shrine of Pandanaran and the sense of community provide a different perspective on the question of difference and heterogeneity in this area. This sense of community also helps us to understand pluralism and where the shrine of Pandanaran stands within the larger question of the religious divide in Bayat. The answer to that question can also help us to make sense of framing Sufi Islam within the larger context of society in Bayat and in Java.

I observed during my fieldwork that the idea of community or collective identity is crucial in Bayat. The collective sense of community is not based on religion or political, economic, or ideological bases. Instead, it is rooted in the idea of place, the piece of sacred nature in which people of different background become one entity. At the shrine of Pandanaran, the cemetery holds graves of different religions. Christian, Muslim, and Hindu are buried side by side. Similar trends are observed in the administrative practices of the shrine of Pandanaran. Muslims and Christians work together during religious and cultural ceremonies. Many families have mixed religious orientations-Muslim women married to Christian men, for example. Extended families still live together, and religion doesn't hinder the unity of family. ${ }^{8}$ 
This sense of the homogenous community formation can also be observed from the social and community work performed collectively by the people of Bayat. Gotong royong or kerja bakti, which means "mutual assistance," is an act of working together for the community without receiving compensation. In gotong royong people provide labor, food, and other resources for construction projects or community services. In the case of construction, materials are paid for through village funds and sometimes also by donation. Food and drinks were also donated by the local community members. Gotong royong provides a good example of the subtleties of the community formation in Bayat. Different religious groups come together for a common social cause.

Pak Warno is Rukun Warga (RW), or village counselor. He is also leader of the local ojek (motorcycle taxi) drivers' association. Pilgrims who can't walk the 250 stairs to reach the tomb of Sunan Pandanaran hire an ojek instead. Pak Warno has also run two cooperative microcredit schemes, one for merchants and one for farmers, successfully since 2008. He is Catholic; his living room has a large cross and an image of Jesus Christ and Mary. In his big, old family house there is a picture with "God Is Love" in English. Next to it is a big photo of Monsignor Jonanos Pujosumarto, the bishop of the Semarang region. Pak Warno goes to mass every Sunday. Rosary prayers are also held at his home on a regular basis.

Pak Warno and people from his area wanted to build another road for the pilgrims, one that was short and close by, so that ojek drivers could take them to the shrine by motorcycle. Once he decided to make this road, he sought approval from the local community leaders of Paseban village. After they agreed to build the road, funds were collected through donations. Some of the funds were provided by the pilgrims, who wanted to get a blessing from the saint. Pak Warno discussed this matter with the community members and ojek drivers and proposed building this road through gotong royong. People from the community and ojek drivers provided labor to complete the road. Muslims and Christians took part in the construction, working hard throughout the hot days of June, July, August, and September.

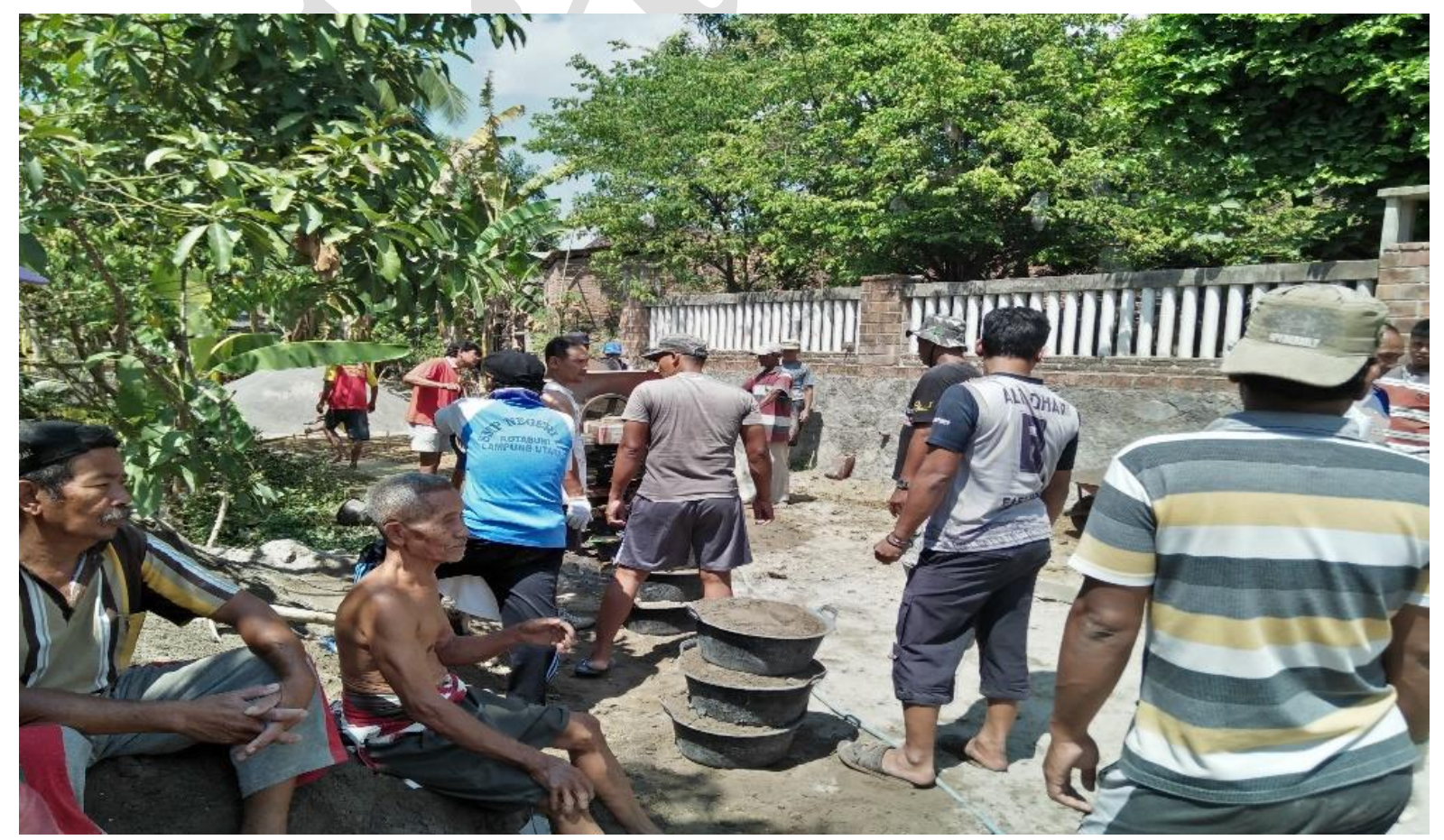

Figure 2. Community members doing gotong royong. 
This work of gotong royong was described as an act of seeking barakah from the saint. It was interesting to observe how many of the Catholic community members, including Pak Warno, Pak Al. Eko Tri Roharjo (the current village chief), and Pak Suripto, worked hard on hot days to seek a blessing from a Muslim saint. What is more interesting is that Catholic villagers were making this road to ease the travel of Muslim pilgrims. The Catholic villagers, by making a road, were making the pilgrimage possible for the old and sick and those unable to climb the stairs comfortably. Thus, the pilgrimage is not just an effort on the part of the pilgrims but the work of the people like Pak Warno, Pak Suripto, and the Catholic and Muslim villagers who made it happen.

Community in Bayat seems to transcend our common definition of the term. On the last gate of the shrine of the Pandanaran, the images of Buddha and Sunan Pandanaran become essentially one. In a similar way, religious differences are muted in the everyday life of Bayat. These daily practices blur the fixed categories of Muslim and Christian based on the textual, canonical, or literary characterizations of religion or religiosity.

\section{Barakah of Ziarah}

It was the peak day of Haul Agung Sunan Pandanaran. Around the shrine of Pandanaran, it was like a carnival. This was the eve of haul agung, or sadrranan, the annual celebration of the veneration of the saint and a day of honoring and remembering deceased ancestors according to Javanese tradition. Near the ticket counter at the entrance, women from all parts of Bayat brought tempah, the food baskets which were full of different items, decorated with beautiful designs. Every tempah bore the name of a person, group, or organization that had brought the food for a blessing from the saint. People also brought tumpeng, mountain-shaped rice, from different councils of Bayat. The official photographer was taking pictures of people posing with their tempah and tumpeng. When everyone was ready, most of the women who had food baskets formed a line to march in the carnival style. On the side of the road, the kapala desa, the village chief of Paseban, along with his wife and other people in formal Javanese dress, were waiting for these women to merge with them. When the group with the food baskets joined the end of the village chief's group, he started to lead the procession, called arak-arakan, which means "marching together." This procession is modelled on the royal courts of Yogyakarta and Surakarta.

In front were the village chief and the dignitaries of the area, followed by different groups of people like Jathilan, ${ }^{9}$ Seni Reog, ${ }^{10}$ women with food baskets, and a musical group. These pilgrims marched all around Paseban and then commenced climbing the 250 stairs to reach the shrine of Pandanaran. All the food baskets were put under the pondopo, the large canopy at the shrine, where prayers were said over the food and offerings given to the ancestors. Tahlil prayers were performed though reciting La illah illa llah, "There is no God but Allah."

After prayers the ustaz, or prayer leader, who is from the family of Sunan Pandanaran and normally leads prayers at the shrine, gave a tray of flowers to Pak Eko and his wife to lead the group of people to the mausoleum of the saint. Pak Eko, with his wife and the ustaz, led the group of people into the mausoleum. The ustaz led the prayers, and Pak Eko and his wife sat next to him and prayed together. After the prayers ended, the ustaz, with Pak Eko and his wife, went inside the small wooden chamber of the tomb and performed the final prayers. After they returned from the grave of Pandanaran, food was distributed among the pilgrims. 


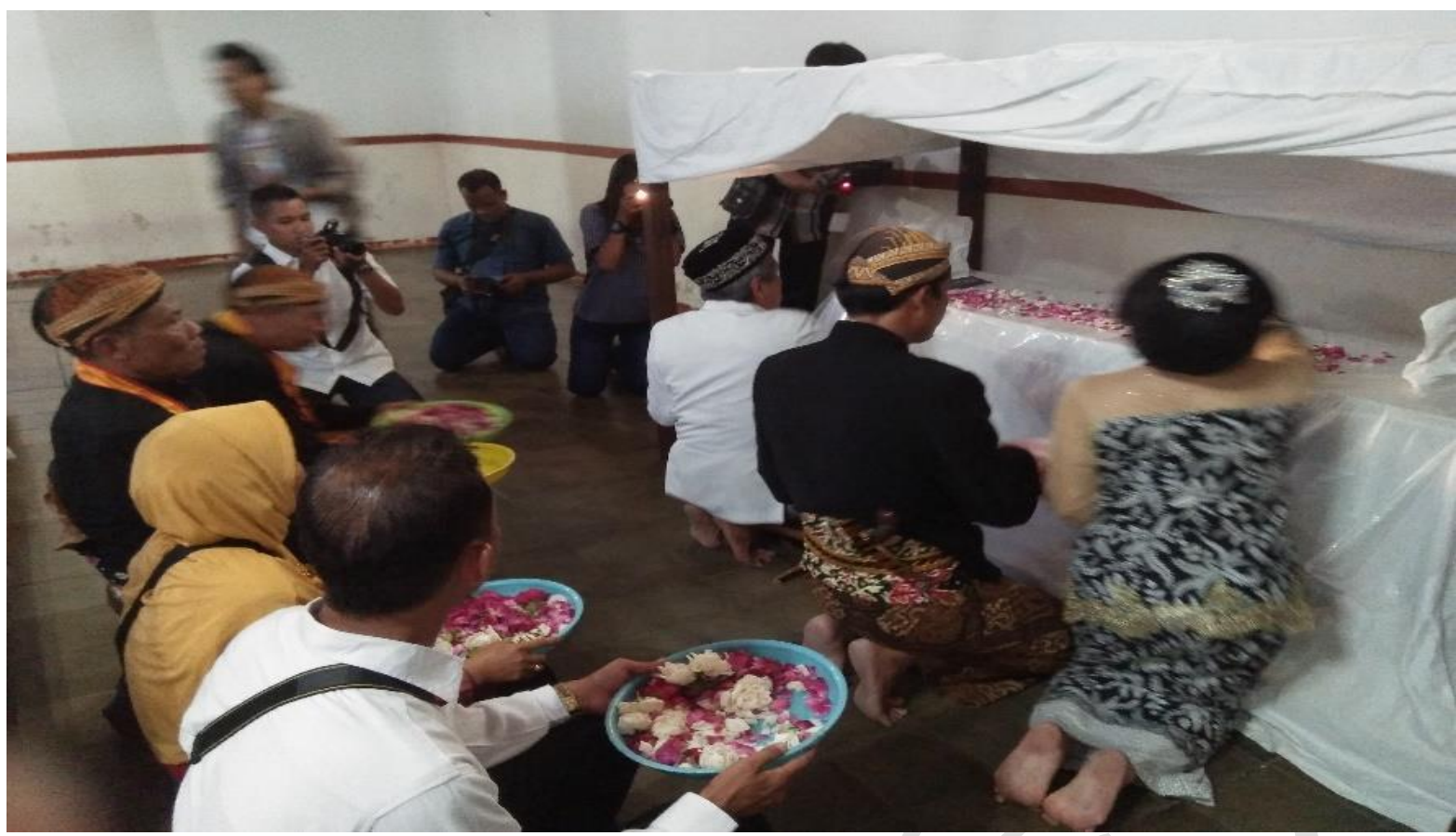

Figure 3. The ustaz leeding the prayers, and Pak Eko and his wife sitting next to him and praying together.

Every year, ten days before the day of the celebration, people conduct the ritual called pasang langse, or putting on new white fabric to cover the graves at Gedung Inten, the main building at the shrine of Sunan Pandanaran. After the prayers at the canopy, Pak Eko initiated the cleaning ceremony at the tomb complex. Many people came to clean the building and remove the stained white fabric. It had been there for a year, and dust had changed the colour from white to nearly gray.

My eyes went to Marni, the only woman in the building. She was not wearing a hijab, or headscarf, like the typical Muslim women do during pilgrimage to a shrine, and she was wearing short trousers, unlike Muslim women, who cover their entire body while visiting the shrines of saints. Marni believes in the traditional Javanese religion, generally referred to as kejawen. She came with her husband and looked busy, making sure that people put the right fabric in the right place. She carried scissors and a measuring tape in a small bag. During the lunch break, I spoke to her:

I am a tailor. I make langse for Sunan Pandanaran every year because I want to get barakah from Kanjeng Sunan. Most of my income is from making school uniforms, and I have three employees. I realized this is because of barakah from Kanjeng Sunan. My life was not easy, and I had a meager amount of food for my family. I kept coming to Kanjeng Sunan to ask for his blessing. Now I have enough. Makam Pandanaran administrator did not pay me enough to make langse, but I am happy to do it with my husband. I do not ask my employees to sew the langse; it is all done by me and my husband. Before me, another person made langse for Kanjeng Sunan. After he passed away, I was asked to make langse for Kanjeng Sunan. I received the blessing. I do not need to leave my village to earn money. I kept requesting a blessing from Kanjeng Sunan Pandanaran for my children. Just like everyone working in this building todaywe all are looking for barakah. 
After the langse was changed, Marni and the others left Gedung Inten. When I passed by the pondopo, I saw that the off-white, nearly gray langse had already been cut into handkerchiefsized pieces. The juru kunci at the registration desk invited me to take one. He said that people kept them for a blessing and protection from danger or an enemy who might take their fortune. As other people did, I put some money in the donation box after I accepted the fabric. The juru kunci said, "You don't need to put money in the donation box. May Kanjeng Sunan Pandanaran bless you, and may you receive barakah."

What is significant about these events is that Pak Eko is a Catholic village chief of Paseban and the son of Pak Suripto, and Marni believes in kejawen. What we observed during the annual death anniversary of the Muslim saint was a transcendence of religious boundaries, showing the different kinds of relationships that people can have with their religion and religiosity in general. These ethnographic encounters provide examples of how the boundaries of local religion do not exclude a Catholic village chief from initiating the annual celebration of a Sufi saint or a kejawen woman from sewing draperies for the shrine of that saint. ${ }^{12}$

What is on the surface a Muslim sacred place can in fact have a much more complex relationship with the surrounding people and culture. These relationships are taken for granted as they have become part of the everyday, mundane routine, but they provide us with a mechanism to rethink what might be possible if we take everyday ethnographic happenings into account. When I asked Pak Suripto about how he, as a Christian, is a devotee of a Muslim saint, he responded, "We are just walking along the footprints of our ancestors. Our ancestors were neither Muslim nor Christian."

The sacred Javanese geography of ziarah at the shrines of saints and ancestors is a way of walking in the footsteps of history or traveling on the path of these saints and ancestors. Ziarah and participating in zikir and ritual celebrations are some of the ways in which people become part of the past and the past comes alive in the present. This continuum defines the spiritual framework in which the common people visit the nine saints of Java and follow their paths to retain their Javanese cultural and religious identity.

\section{Conclusion}

The shrine of Pandanaran is a historically sacred place, and the courts of Yogyakarta and Surakarta claim Sunan Pandanaran as an important ancestor of the royal family of Mataram Kingdom. However, in modern times, the resurgence of the shrine of Pandanaran provides a different narrative of the spiritual spaces of Java. Why have two Catholics elevated the shrine to make it a prominent sacred space again? Such questions might not seem important in the context of Indonesian studies or studies of Islam in Java, but, on the basis of the ethnographic examples I provided from Bayat, we may need to think differently about sacred space, spirituality, and the ideas of diversity, multiplicity, heterogeneity, and alterity when it comes to the shrine of Pandanaran.

We were in the state of zikir, where it seems everything is in a state of perpetual suspension. We kept reciting La illah illa llah, "there is no God but Allah," in the zikir called the Tahlil, under the canopy at the shrine of Pandanaran: twenty-one people in traditional Javanese dress either reading from Jamaah Dzikir Puji Sampurno Padang Aran Paseban Bayat or sitting with eyes closed. Heads were moving fast to the left and right in rhythm like the old German clock's pendulum. Occasionally, the intensity of zikir pulled me out of this moment in time. My body 
seemed annihilated in the ephemeral space. Time and space had no boundaries. The musical rhythms of Tahlil generated a vibe of spiritual otherworldliness. Images of a meditating Buddha, a dragon, a gapura, and Sunan Pandanaran in the picture of nine saints in the market of Bayat were revolving around us. Everything was moving. I had the feeling that all who were present under the canopy were continuously in motion. I began to travel from the shrine of Pandanaran to somewhere, to nowhere, to everywhere, to Austin, ${ }^{13}$ to the shrine of Shah Abdul Latif Bhittai in Sindh, ${ }^{14}$ to the shrine of Sunan Kalijaga, to the grand mosque of Demak in the solo flight of my meditation.

I felt as if my soul and inner being were separate from my body. My body seemed like a barrier to the liberation of my soul. The inner urge produced in the state of zikir made me feel like an ethereal element, like being under a mystical spell. I felt a seeking for the door to liberty, a subconscious sensation of restless waves rolling away from the obstruction of my body. Buddha, a dragon, a gapura, and Sunan Pandanaran's image kept flashing in and out of dark circles and rays of white light like distant fireflies. It was an hour-long session, but when it ended, it felt like a few seconds of reflection. There were a few minutes of disorientation before I returned to a normal state, sitting under the canopy.

As soon as zikir is over, food is served. Drinking tea and eating snacks remind you that you are back in the physical world. It was during a zikir Tahlil session early in my fieldwork that someone from the group gave me a book titled Jamaah Dzikir Puji Sampurno Padang Aran Paseban Bayat, "The Group of Perfect Worship of Pandanaran Paseban, Bayat." This book bore the name of the village chief, Al. Eko Tri Raharjo, or Pak Eko. Similar books can be found everywhere in Indonesia. People publish them to earn blessings, as it is believed that if someone reads the sacred verses, the person who published or distributed the material receives equal barakah from Allah. What is interesting about Pak Eko's book, the people working at the shrine and participating in the zikir tell me, is that zikir Tahlil was suspended by the previous village chief. When Pak Eko won the election, he decided to reinstate zikir Tahlil. People in Bayat believe that because of this act, Pak Eko receives barakah from Allah.

La illah illa llah-“There is no God but Allah"-is recited by new converts to Islam. According to many Sufis, La illah illa llah cleans the hearts of the people and provides a continuous opportunity to profess the faith of Islam whenever they are engaged in zikir Tahlil. Zikir is so important that many Sufis engage in it every night to keep renewing their faith. Pak Eko, through reestablishing the tradition of zikir Tahlil and making the book available for the people who can't memorize it, provides a way for them to earn barakah from Allah and renew their faith every time they conduct zikir. It is generally believed that only Muslims make efforts to renew the faith of another Muslim. However, this act of renewal was initiated by a Catholic village chief who keeps the Sufi tradition alive through reinvention, despite the previous Muslim village chief, who tried to end it.

Like the meditating Buddha, dragons, and a gapura that create a mutable landscape, Pak Eko's action to keep renewing the faith of Muslims through zikir Tahlil is decidedly undecided. This fluidity at the shrine of Sunan Pandanaran at Bayat allows the unnoticed, the inconspicuous, and the unobtrusive in everyday life to perpetuate through their own ways of happening (Highmore 2002). What lingers is not the iconography, the meditating Buddha, dragons, and a gapura, but the potency of the spirit. Zikir Tahlil is defined as a state of suspension, ceasing to become but always in the state of becoming. In the repetition of the Tahlil, suspension generates the power of the place. It is within this creative tension that we may need to look to understand 
the sources of heterogeneity, multiplicity, and difference within the very essence of the Sufi tradition of Sunan Pandanaran, where the state of being is decidedly unfixed. The shrine is not just a living spring of mutability; it has the potential to generate a state of suspension through constant zikir, day and night, year round, to form rhizomatic symbiosis, which is the source of its perpetuity. It is within these everyday occurrences that we may be able to share the universal experience of the shrine of Pandanaran.

In the experience of being at the shrine of Pandanaran, attending zikir, and meditating at the tomb of the saint, one may find what it means to be Hindu, Buddhist, Christian, Muslim, or everything together-retaining the difference but essentially becoming one, like Shiva and Buddha, or Buddha and Pandanaran, or like Pak Eko, Catholic but helping Muslims renew their faith through zikir.

\section{Acknowledgments}

I am grateful to the Sunan Kalijaga State Islamic University in Yogyakarta, Indonesia for providing me an opportunity of a Sunan Kalijaga International Postdoctoral Fellowship (SKIPF). Generally referred to as UIN Yogyakarta, it has provided an accommodation at the Club House, library support, and a chance to interact with the Indonesian and the international scholars. I am especially thankful to Professor K. H. Yudian Wahyudi, Dr. Phil. Sahiron Syamsuddin, Labibah Zain, Tantri Yuniarti, Pak Wawan, and Lien Iffah Naf'atu Fina for making this research possible and helping me to navigate Yogyakarta and attend many relevant events. I am also thankful to the Ministry of Religious Affairs, Republic of Indonesia, and specially the Minister Lukman Hakim Saifuddin and the Director General of Islamic Education within the Ministry of Religious Affairs, Prof. Dr. Phil. H. Kamaruddin Amin.

\section{References}

Abun-Nasr, J. M. (1965). The Tijaniyya, a Sufi order in the modern world. Oxford University. Al-Šāfīī, M. B. I. (2011). Al-Imām Muhammad ibn Idris al-Shāfi 'ı̀'s al-Risāla fì uṣūl al-fiqh: Treatise on the foundations of Islamic jurisprudence, translated by Majid Khadduri. The Islamic Texts Society. https://www.amazon.com/Al-Shafiis-Risala-TreatiseFoundations-Jurisprudence/dp/0946621152

Anderson, B. (2006). Imagined Communities. Verso [1983]. https://is.muni.cz/el/1423/podzim2013/soc571e/um/anderson_b_imagined_communities.pdf

Beatty, A. (1996). Adam and Eve and Vishnu: Syncretism in the Javanese Slametan. Journal of the Royal Anthropological Institute, 2(2), 271-288. https://doi.org/10.2307/3034096

Beiner, R. (1984). Walter Benjamin's Philosophy of History. Political Theory 12(3), 423-434. https://doi.org/10.1177/0090591784012003005

Bellamy, C. (2011). The Powerful Ephemeral: Everyday Healing in an Ambiguously Islamic Place. University of California.

Bowen, J. R. (1986). On the Political Construction of Tradition: Gotong Royong in Indonesia. The Journal of Asian Studies, 45(3), 545-561. https://www.jstor.org/stable/i309688

Chang, A. H. (2001). Shah Jo Raag: A Sufi Musical Tradition of Sindh. A case study in ethnomusicology. Unpublished MA thesis, Department of Anthropology, Quaid-IAzam University, Islamabad. 
Christomy, T. (2008). Signs of the wali: Narratives at the sacred sites in Pamijahan, West Java. Canberra. ANU E.

Dehlvi, S. (2012). The Sufi courtyard: Dargahs of Delhi. Harper Collins.

Gibson, T. (2000). Islam and the Spirit Cults in New Order Indonesia: Global Flows vs. Local Knowledge. Indonesia 69: 41-70. https://doi.org/10.2307/3351276

Gilsenan, M. (1973). Saint and Sufi in Modern Egypt. An Essay in the Sociology of Religion. Oxford - Clarendon.

Griffiths, A. (2012). The epigraphical collection of Museum Ranggawarsita in Semarang (Central Java, Indonesia). Journal of the Humanities and Social Sciences of Southeast Asia and Oceania 168(4), 472-496. https://halshs.archives-ouvertes.fr/halshs$\underline{01957963 / \text { document }}$

Headley, S. C. (2000). Javanese Cosmogonies and Muslim Cosmographies: An Encompassing Knowledge? Indones. Malay World 28(82), 280-300. https://doi.org/10.1080/13639810020022742

Highmore, B. (2002). Everyday Life and Cultural Theory: An Introduction. Routledge.

Jaques, R. K. (2006). Sajarah Leluhur: Hindu Cosmology and the Construction of Javanese Muslim Genealogical Authority. Journal of Islam Studies, 17(2), 129-157. https://doi.org/10.1093/jis/etl004

Kinney, A. R., Klokke, M. J., Kieven, L. (2003). Worshiping Siva and Buddha: The Temple Art of East Java. University of Hawai'i.

Kreinath, J. (2012). The Anthropology of Islam Reader. Routledge.

Kunst, J. (1949). Music in Java: Its History, Its Theory and Its Technique. Martinus Nijhoff.

Laksana, A. B. (2014). Muslim and Catholic pilgrimage practices: Explorations through Java. Ashgate.

Lawrence, B., \& Ernst, C. W. (2002). Sufi Martyrs of Love: The Chishti Order in South Asia and Beyond. Palgrave Macmillan.

Levenda, P. (2011). Tantric temples: Eros and magic in Java. IBIS.

Lowy, M. (2005). Fire alarm: Reading Walter Benjamin's on the concept of history. Verso.

Marranci, G. (2008). The Anthropology of Islam. Berg.

Ricklefs, M. C. (1978). Modern Javanese historical tradition: a study of an original Kartasura chronicle and related materials. SOAS, University of London.

Ricklefs, M. C. (1998). The seen and unseen worlds in Java, 1726-1749: History, literature and Islam in the court of Pakubuwana II. Allen \& Unwin.

Ricklefs, M. C. (1998). Babad Sangkala and the Javanese sense of history. Archipel 55, 125140. https://www.persee.fr/doc/arch_0044-8613_1998_num_55_1_3445

Ricklefs, M. C. (1998). Islamising Java: the long shadow of Sultan Agung. Archipel 56, 469482. https://www.persee.fr/doc/arch_0044-8613_1998_num_56_1_3503

Ricklefs, M. C. (2006). Mystic synthesis in Java: a history of Islamization from the Fourteenth to the early Nineteenth Centuries. East Bridge.

Ricklefs, M. C. (2012). Islamisation and its opponents in Java: a political, social, cultural and religious history, c. 1930 to the present. NUS. https://doi.org/10.2307/j.ctv1qv3fh

Ricklefs, M. C., Lockhart, B., \& Lau, A. (2010). A new history of Southeast Asia. Palgrave Macmillan.

Sumarsam. (1995). Gamelan: Cultural Interaction and Musical Development in Central Java. University of Chicago.

Trimingham, J. S. (1998). The Sufi orders in Islam. 2nd ed. Oxford University.

Van-Bruinessen, M. (1998). Studies of Sufism and the Sufi Orders in Indonesia. Die Welt des Islams. 38(2), 192-219. https://doi.org/10.1163/1570060981254813 
Wieringa, E. (1999). An old text brought to life again; A reconsideration of the 'final version' of the Babad Tanah Jawi. Bijdragen tot de Taal-, Land-en Volkenkunde 155(2), 244-263. https://www.jstor.org/stable/27865516

\section{Notes:}

1 Krishna is a major deity in Hinduism.

2 The shrine complex of Pandanaran was constructed by the Sultan Agung Adi Prabu Hanyakrakusuma (1593-1645), third king of Mataram Kingdom in central Java. He ruled from 1613 to 1645. Sultan Agung's reign is considered a golden time for the Mataram Kingdom.

3 According to Sufis, the Tahlil means being in a state of suspension. It is recited when someone converts to Islam from another religion and generally refers to the confession of Islamic faith.

4 'In the words of old Javanese text Sutasoma, 'bhinneka tunggal ika,' which translates as unity in diversity and [has] become the motto of [the] Indonesian Republic, Siva and Buddha are described as different but essentially one.” Ann R. Kinney et al, Worshiping Siva and Buddha: The Temple Art of East Java (Honolulu: University of Hawai'i Press, 2003), 24.

5 Pak Suripto, a Catholic mayor of Paseban village from 1974 to 1990, has developed this sacred place with the help of the community.

6 By September 2017 entry fees is 1000 IDR.

${ }^{7}$ The Nahdlatul Ulama is the second-largest Muslim organization in Indonesia. It follows traditional and Sufi Islamic values, and its followers respect local cultural traditions. It supports democracy and is against making Indonesia an Islamic caliphate. The Nahdlatul Ulama cadre follows the Pancasila philosophy.

8 Such examples are hardly considered normal in South Asia and most of the Middle East, where religion has become a major source of division between Muslim and non-Muslim communities.

9 Jathilan is a mythical horse-riding dance performed to traditional Javanese music. The players dance a horse dance in a group, and at the end of the performance, some of the players enter a trance. During this state they become out of control. They fight with the audience, eat stones and coconut shells, and even bite a live chicken in the neck. It is believed that these players are possessed by different supernatural entities.

${ }^{10} \mathrm{Reog}$ is a traditional dance where dancers cover their faces with huge lion masks. In Reog the mystical story of war is enacted through an intense trance.

11 The juru kunci's brothers are Catholic, and he and his other brother are Muslim. His father and mother had kejawen beliefs. His father was also juru kunci at the shrine of Pandanaran.

${ }^{12}$ In South Asia the moments of cleaning and purifying the Muslim shrines with water and changing the fabrics at the shrines are restricted, and non-Muslims are asked to leave the premises. It is believed that the presence of non-Muslims during cleaning and purifying will pollute the shrine.

${ }^{13}$ I went to graduate school in the Department of Anthropology at the University of Texas at Austin and am affiliated with it.

${ }^{14}$ Shah Abdul Latif Bhittai is a famous Sindhi poet and eighteenth-century Sufi saint. He is considered the patron saint of Sindh. I have conducted many years of ethnographic fieldwork at the shrine of Shah Abdul Latif Bhittai. At the shrine of Pandanaran during the zikir, 1 always felt closer to the shrine of Shah Abdul Latif Bhittai. See also Abdul Haque Chang, "Shah Jo Raag: A Sufi Musical Tradition of Sindh. A case study in ethnomusicology." Unpublished MA thesis, Department of Anthropology, Quaid-I-Azam University, Islamabad, 2001. 